\title{
Some reproductive traits of three fish species from Lake Ayamé 1 of the South-Eastern Côte d'Ivoire
}

\author{
Kessié B. A., Konan Y. A.*, Kamelan T. M. and Kouamélan E. P. \\ Laboratory of Hydrobiology, Department of Biosciences, University of Félix Houphouët-Boigny, 22 BP 582 Abidjan 22 , \\ Côte d'Ivoire.
}

Accepted 12 March, 2019

\begin{abstract}
This study was carried out to update some data on reproductive parameters of Sarotherodon melanotheron $(n=617)$, Chrysichthys nigrodigitatus $(n=545)$ and Brycinus macrolepidotus $(n=498)$ from Lake Ayamé 1. Samples were collected on monthly basis, between September 2017 and August 2018 using gillnets of various sizes. Based on gonadosomatic index (GSI) and maturity stages, $S$. melanotheron and $B$. macrolepidotus exhibited two spawning periods while $C$. nigrodigitatus reproduced during a single period, which coincided with the rainy seasons (March to July and October to November). In S. melanotheron and C. nigrodigitatus, males reached the first sexual maturity size $\left(S L_{50}\right)$ at smaller length than female with the $\mathrm{SL}_{50}$ obtained are lower than those observed in the same lake or in other ecosystems. Absolute fecundity is positively related to standard length and body weight. Relative fecundity ranged from 1 to 294 oocytes per $g$ of body weight in these species and the trend of increasing of fecundity was observed reflecting a possible adaptation to fishing pressures.
\end{abstract}

Keywords: Fish, size, fecundity, gonadosomatic index, ovary maturity, Lake Ayamé 1.

*Corresponding author. E-mail: ariskoya@yahoo.fr.

\section{INTRODUCTION}

Interest toward the biology of reproduction of teleost fish has increased considerably over the past few years due to the environmental and economic importance of several species. To manage fishery, it is necessary to determine the spawning periods of species living in the area being fished, to identify the ideal time and duration for a ban and also to take socio-economic factors into account. Indeed a knowledge of fecundity is important in stock size estimation and stock discrimination (Lévêque et al., 2006; Costa et al., 2015) within an ecosystem.

Lake Ayamé 1 is the site of significant fishing activity in south-eastern Côte d'Ivoire and Sarotherodon melanotheron Rüppell, 1852, Chrysichthys nigrodigitatus (Lacepède, 1803), Brycinus macrolepidotus Valenciennes, 1849 are highly valued fish species in this area and are subjected to high fishing pressure (Vanga, 2004; Tah et al., 2009). The first species occurs in lagoons and estuaries from Mauritania to Cameroon (Teugels and Thys Van Den Audenaerde, 2003), the second is known from most West Africa basins, extending from Senegal to Angola (Risch, 2003) and the third occurs almost throughout intertropical Africa (Paugy, 2003). Several data on the biology and ecology of these species are available (Koné and Teugels, 1999; Ouattara et al., 2006), including breeding periods but other reproductive traits such as first maturity size and fertility are less known. In a tactical response to the changeable environment, some reproductive traits (e.g. fecundity, maturity size, reproductive season) may exhibit an adaptative behavior which responds to physiological trade-off between reproduction and growth, reproduction and condition, as well as the number and quality of the offspring (Stearns, 1992). While environmental factors, such as temperature and hydrological seasons, cause medium and long term changes in many biological traits of fish (Brooks et al., 1997; Lambert et al., 2003), fishing activities itself can produce rapid alterations (SaboridoRey and Kjesbu, 2005). Fishery often creates preference 
for the larger fish thus, inducing changes in the age structure of the population. As a result of this compensatory mechanism, fish mature at earlier age and at smaller size (Rochet, 2000) which negatively affecting the reproductive potential of the population (Trippel et al., 1997).

Fishing activities in Lake Ayamé 1 was mainly dominated by non-native fishermen at $74.6 \%$ (Vanga, 2004). Several authors had shown that, the exploitation of lake by these fishermen contributed to overexploitation of resources (Tah et al., 2009) which results in depletion of stocks, morphological and physiological adaptation of fish of this area, hence the need to update information on fish population structure in Lake Ayamé 1. This study was carried out to update data on the reproductive parameters of $S$. melanotheron, $C$. nigrodigitatus and $B$. macrolepidotus from Lake Ayamé 1 based on their spawning aspects, fecundity and to relate it to the length, size of first maturity. The information provided can be used for future fisheries management and regulation of Lake Ayamé 1.

\section{MATERIALS AND METHODS}

\section{Study area}

Lake Ayamé 1 is located in the South-East $\left(05^{\circ} 30^{\prime} \mathrm{N}, 03^{\circ} 00^{\prime} \mathrm{W}\right.$; Figure 1). Its climate is characterized by an equatorial transition zone, with two rainy seasons (April to July and October to November) separated by a short dry period from August to September, and a more pronounced one from December to March. Hydroelectric reservoir was built on the Bia River and has an average surface of $135 \mathrm{~km}^{2}$ (Laë, 1997), $80 \mathrm{~km}$ long and $27 \mathrm{~km}$ wide (at the maximum water level).

\section{Data sampling}

Six hundred and seventeen, 545 and 498 samples of $S$. melanotheron, $C$. nigrodigitatus and $B$. macrolepidotus, respectively were collected on monthly basis, from September 2017 to August 2018, using gillnets (mesh size 10, 15, 20, 25, 30, 35, 40, 45 and $55 \mathrm{~mm}$ ). During each sampling, measurements of standard length (in $\mathrm{cm}$ ) and total weight (in $\mathrm{g}$ ) were taken for each sample. The sex of each specimen was identified and confirmed after dissection and visual examination of the gonads. The gonads were detached from the other visceral organs and weighed. A five-stage maturity based on macroscopic characteristics; $S$. melanotheron and $B$. macrolepidotus according to Koné and Teugels (1999); C. nigrodigitatus according to Lalèyè (1995) was used to classify the gonads.

In order to monitor the sexual cycle and determine the spawning period, the percentage of different stages of sexual maturity and the average of the gonado-somatic index (GSI) were calculated monthly for females: GSI $(\%)=(\mathrm{Wg} / \mathrm{Wev}) \times 100$ where $\mathrm{Wg}=$ Ovary weight (g); Wev = Eviscerated Body weight (g). Monthly variations in percentage of maturity stages (III, IV and V) and GSI were coupled together to determine the breeding periods (Durand and Loubens, 1970; Ouattara et al., 2006).

For the estimation of fecundity, the ovaries of mature females were weighed; three sub-samples were taken from the front, midand rear sections of each ovary and weighed. The total number of eggs in each ovary sub-sample was then proportionally estimated using the equation, F1 = gonad weight $\times$ number of eggs in the subsample / sub-sample weight (Yeldan and Avsar, 2000). Later, by taking the mean number of three sub-sample fecundities (F1, F2, F3), the total fecundity (number of eggs present in the ovary) for each female fish was estimated $F a=(F 1+F 2+F 3) / 3$. In addition, individual fecundity was divided by eviscerated body weight of the fish to estimate relative fecundity $(\mathrm{Fr})$ (number of eggs per gram body weight). Fecundity-standard length, fecundity- bodyweight relationships were determined using the expression: $\mathrm{F}=\mathrm{a} \times \mathrm{b}, \mathrm{F}=$ absolute fecundity, $\mathrm{x}=$ standard length or body weight, $\mathrm{a}=$ constant, $\mathrm{b}=$ regression coefficient was evaluated by least squares regression analysis using log transformed data based on the formula: $\log F=\log a+b \log x i$.

The size at first maturity is the size at which $50 \%$ of individuals are mature $\left(\mathrm{SL}_{50}\right)$. During the reproduction season, the collected individuals were classified as mature and immature individuals. Mature individuals with gonads in stages III, IV and V were classified by size class at an interval of $20 \mathrm{~mm}$. The proportions of mature individuals $(\mathrm{Pr})$ and their corresponding size classes were adjusted to a logistic curve (Saila et al., 1988) such as: $\operatorname{Pr}=1 /(1+$ $\left.\mathrm{e}^{-\mathrm{r}(\mathrm{SL}-\mathrm{SL}}{ }_{50} 0^{\prime}\right)$.

The Statistica software package (Version 7.1; Statsoft, Inc.) was utilised to conduct the analysis.

\section{RESULTS}

\section{GSI and maturity stages}

Figure 2 shows that the gonadosomatic index (GSI) for females of $S$. melanotheron. GSI values were ranged from 0.25 to $3.29 \%$ with the main peaks occur in November 2017 (2.51\%) and March (3.29\%). The mean GSI values decreased from 2.51 in November to 0.83 in December. High proportions of mature females (more than $60 \%$ ) were observed during October-December and March-August periods. GSI values reached a single peak in June $(18.74 \%)$ in females of $C$. nigrodigitatus (Figure $3)$. Growth and decline phases of GSI values were observed in February-June and June-August, respectively. Relatively low GSI values from September to February $(0.95$ to $0.49 \%)$ and highest proportions of mature females were observed between April and June. GSI values increased from $0.11 \%$ in October to $7.03 \%$ in June and decreased between September-January and June-July periods in B. macrolepidotus (Figure 4). GSI reached two peaks in September $(9.73 \%)$ and June (7.03\%). Monthly variation of GSI was relatively similar to the percentage of maturity stages. Females at the postlaying stage (V) were observed from June to September among the three species.

\section{Size at first maturity}

The logistic curves describing the relationship between sexes and the proportion of $50 \%$ maturity was estimated and attained $125 \mathrm{~mm}$ in male and $119 \mathrm{~mm}$ in female of $S$. melanotheron (Figure 5A). Sizes of the smallest mature individuals were 93 and $90 \mathrm{~mm}$ in males and females, respectively. In C. nigrodigitatus, $\mathrm{SL}_{50}$ was estimated at 


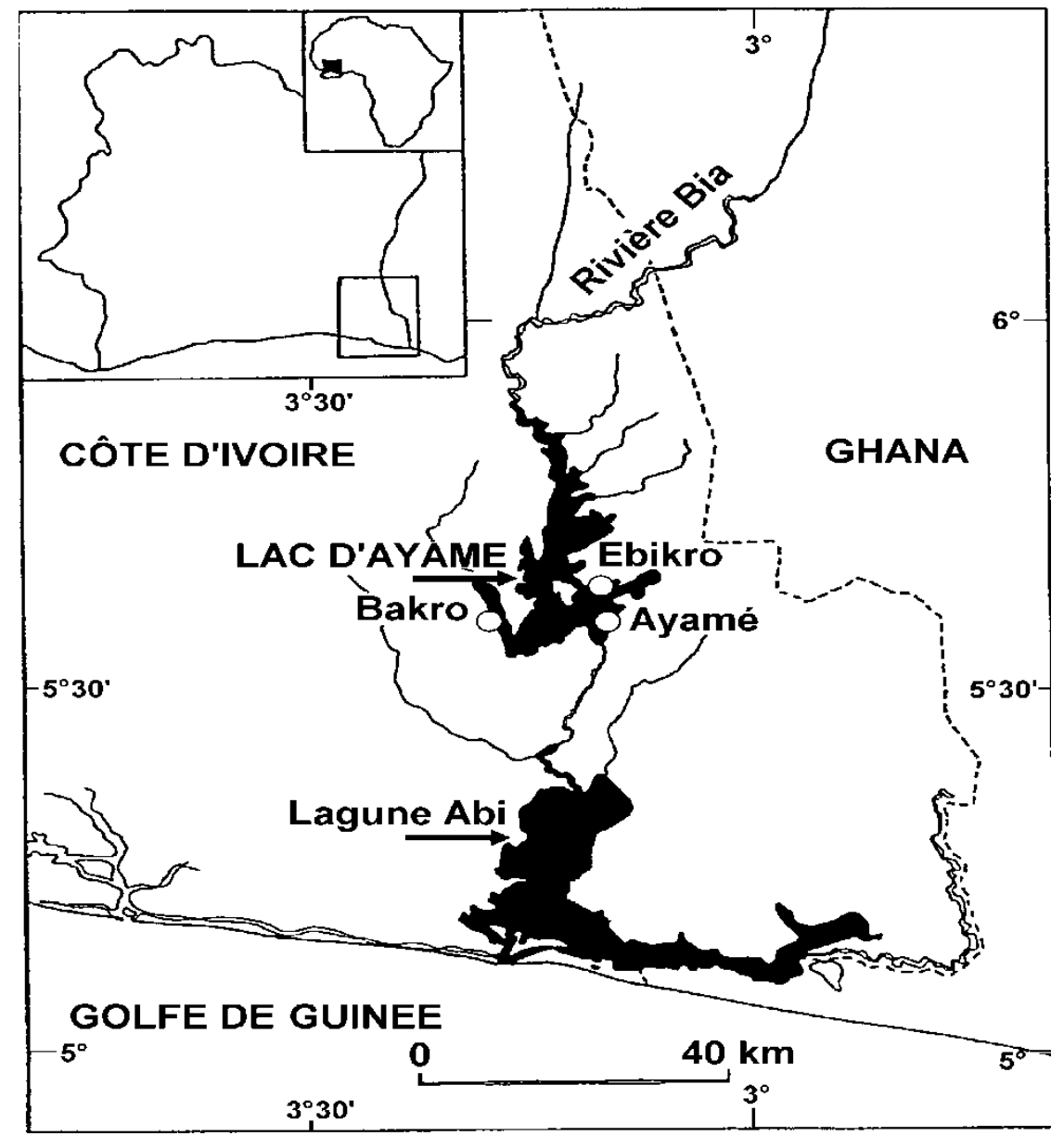

Figure 1. Geographical location of the sampling stations at Lake Ayamé 1 (Koné, 2000).

178 and $184 \mathrm{~mm}$ in males and females, respectively (Figure 5B) and the smallest mature males and females observed measured $113 \mathrm{~mm}$ and $95 \mathrm{~mm}$. While for $B$. macrolepidotus, $\mathrm{LS}_{50}$ was 106 and $88 \mathrm{~mm}$ in males and females (Figure 5C), while the smallest individuals measured 80 and $70 \mathrm{~mm}$ in both sexes, respectively.

\section{Fecundity}

The mean absolute fecundity of $S$. melanotheron was $386 \pm 146$, ranging from 135 to 768 eggs (for a female with a SL ranging from 150 and $220 \mathrm{~mm}$ ) and the relative fecundity ranged from 1 to 4 (mean $2.0 \pm 0.5$ ) in lake Ayamé 1 (Table 1). The mean absolute fecundity of $C$. nigrodigitatus and $B$. macrolepidotus was $4307 \pm 1649$ and $22243 \pm 14331$, respectively and the relative fecundity ranged from 15 to 294 for both fish.

The regression models of the relationship of fecundity with standard length and body weight were expressed as: S. melanotheron: Log $\mathrm{Fa}=0.7124 \log \mathrm{W}+0.94, \mathrm{n}=27$, $\mathrm{R}^{2}=0.6024$ (Figure 6); C. nigrodigitatus: Log $\mathrm{Fa}=$
2.0965Log SL - 1.2717, $n=42, R^{2}=0.761$ (Figure 7A); B. macrolepidotus: $\log \mathrm{Fa}=4.6089 \mathrm{Log} \mathrm{SL}-6.2051, \mathrm{n}=$ $24, R^{2}=0.5222$ (Figure 7B). Significant linear relationships were found for Fa-SL and Fa-W log transformed $(p<0.001)$.

\section{DISCUSSION}

This study indicated variations of maturity stages and the spawning periods of three species of fish from Lake Ayamé 1. High proportions of mature females and the peak of GSI were mainly observed between April and August. The breeding periods of these species generally coincided with rainy seasons in Lake Ayamé 1. Indeed, most freshwater fish species of the intertropical zone become ripe then lay at the time of the rise of water which follows the beginning of the rainy season (LoweMcConnell, 1975). In the same way, in African rivers, the risings of water levels are the determining factors in the reproductive biology of the fishes (Welcomme and de Merona, 1988). The analysis of the results relating to 

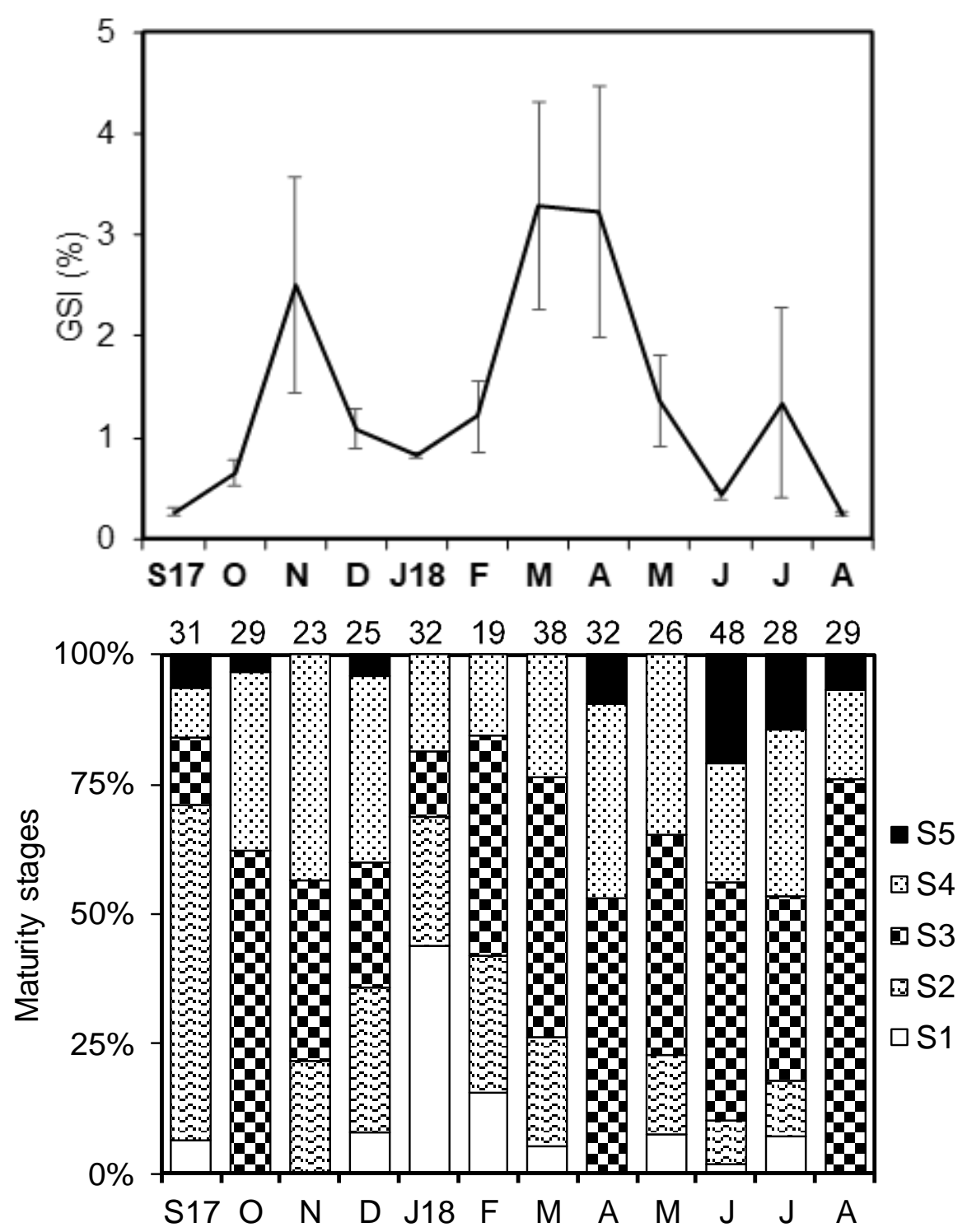

Figure 2. Monthly variation of GSI and maturity stages (S1-S5) in females of $S$. melanotheron $(\mathrm{N}=360)$ from Lake Ayamé 1 between September 2017 to August 2018. Number of individuals sampled per month is indicated in bar graph.
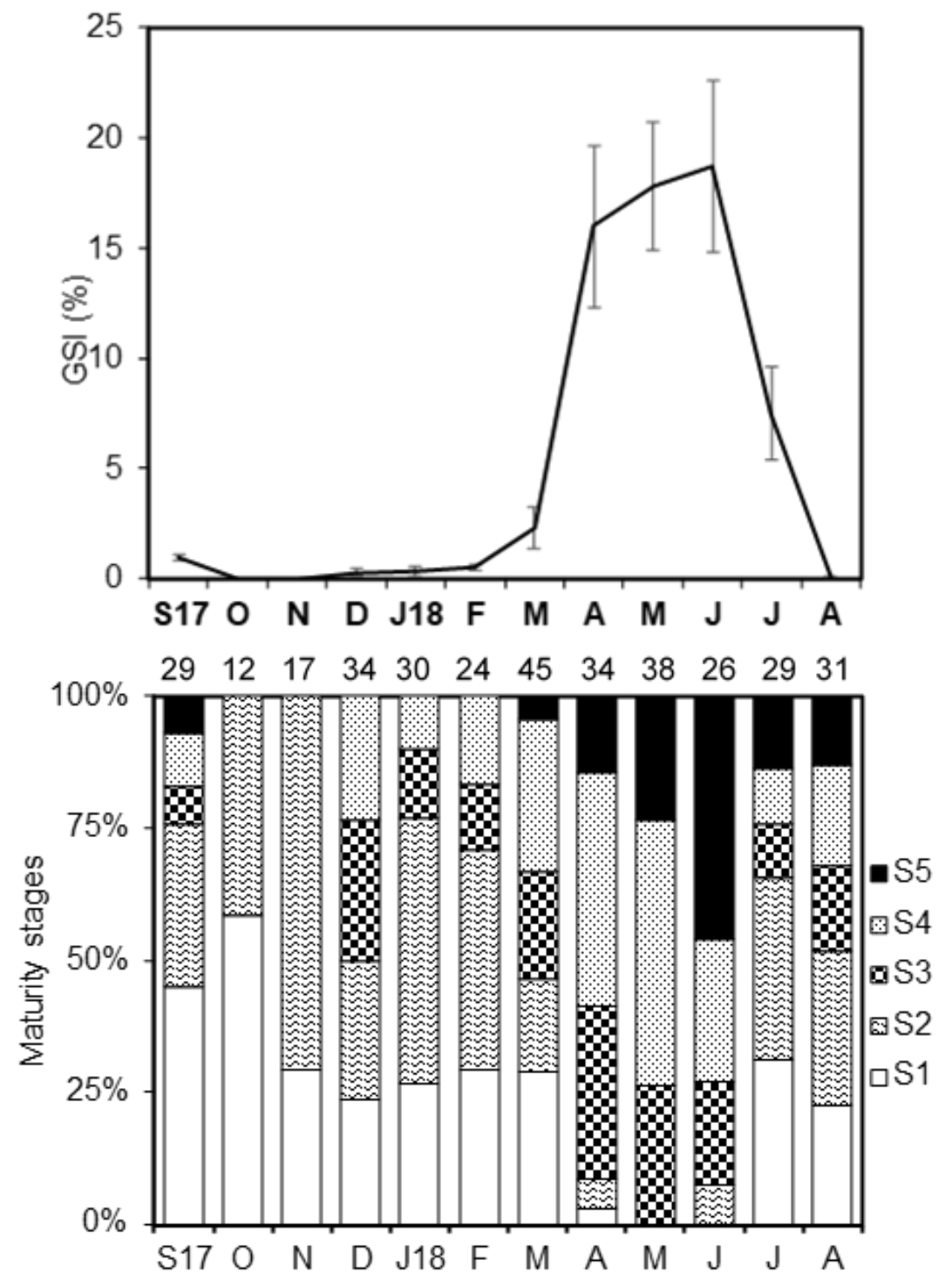

Figure 3. Monthly variation of GSI and maturity stages (S1-S5) in females of Chrysichthys nigrodigitatus $(\mathrm{N}=349)$ from Lake Ayamé 1 between September 2017 and August 2018. Number of individuals sampled per month is indicated in bar graph. 


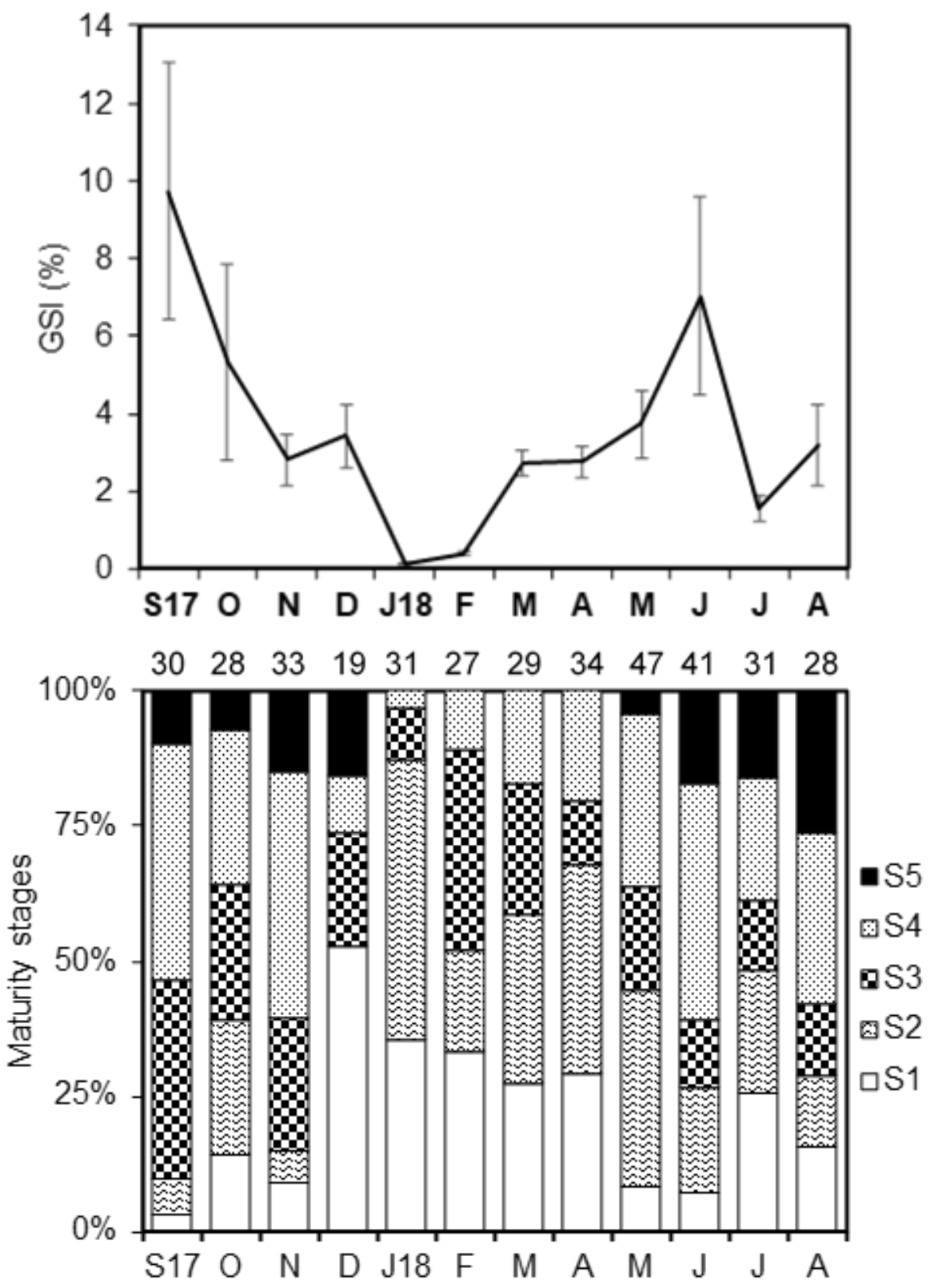

Figure 4. Monthly variation of GSI and maturity stages (S1-S5) in females of Brycinus macrolepidotus $(\mathrm{N}=388$ ) from lake Ayamé 1 between September 2017 and August 2018. Number of individuals sampled per month is indicated in bar graph.

sexual maturity stages and GSI of these species taken in Lake Ayamé 1 forms part well of this strategy. Previous studies conducted in Lake Ayamé 1 have also shown that $S$. melanotheron and $B$. macrolepidotus breed during rainy seasons (Koné and Teugels, 1999; Ouattara et al., 2006). According to Lévêque et al. (2006), this reproductive pattern in tropical areas reflects adaptation to environmental constraints to optimize release of gametes in a synchronized process related to food availability for larvae and post larvae. This ensures a greater survival of the offspring. This type of reproductive behavior was also observed in other species, for instance
Clarias buettikoferi in Tanoé-Ehy swamp forest (Konan et al., 2014) and 18 fish species in Baoulé River (Paugy, 2002).

The size at first maturity of three fish species showed some variations in males and females. Namely $\mathrm{SL}_{50}$ was estimated as $119 \mathrm{~mm}$ in females and $125 \mathrm{~mm}$ in males for S. melanotheron, respectively. These values were lower than that reported for the same species in Lake Ayamé I $\left(\mathrm{SL}_{50}=126 \mathrm{~mm} ; \mathrm{SL}_{50}=136 \mathrm{~mm}\right)$ (Koné and Teugels, 1999). Similarly, the first sexual maturity sizes of C. nigrodigitatus $\left(\mathrm{SL}_{50}=178 \mathrm{~mm} ; \mathrm{SL}_{50}=184 \mathrm{~mm}\right)$ and B. macrolepidotus $\left(\mathrm{SL}_{50}=106 \mathrm{~mm} ; \mathrm{SL}_{50}=88 \mathrm{~mm}\right)$ 

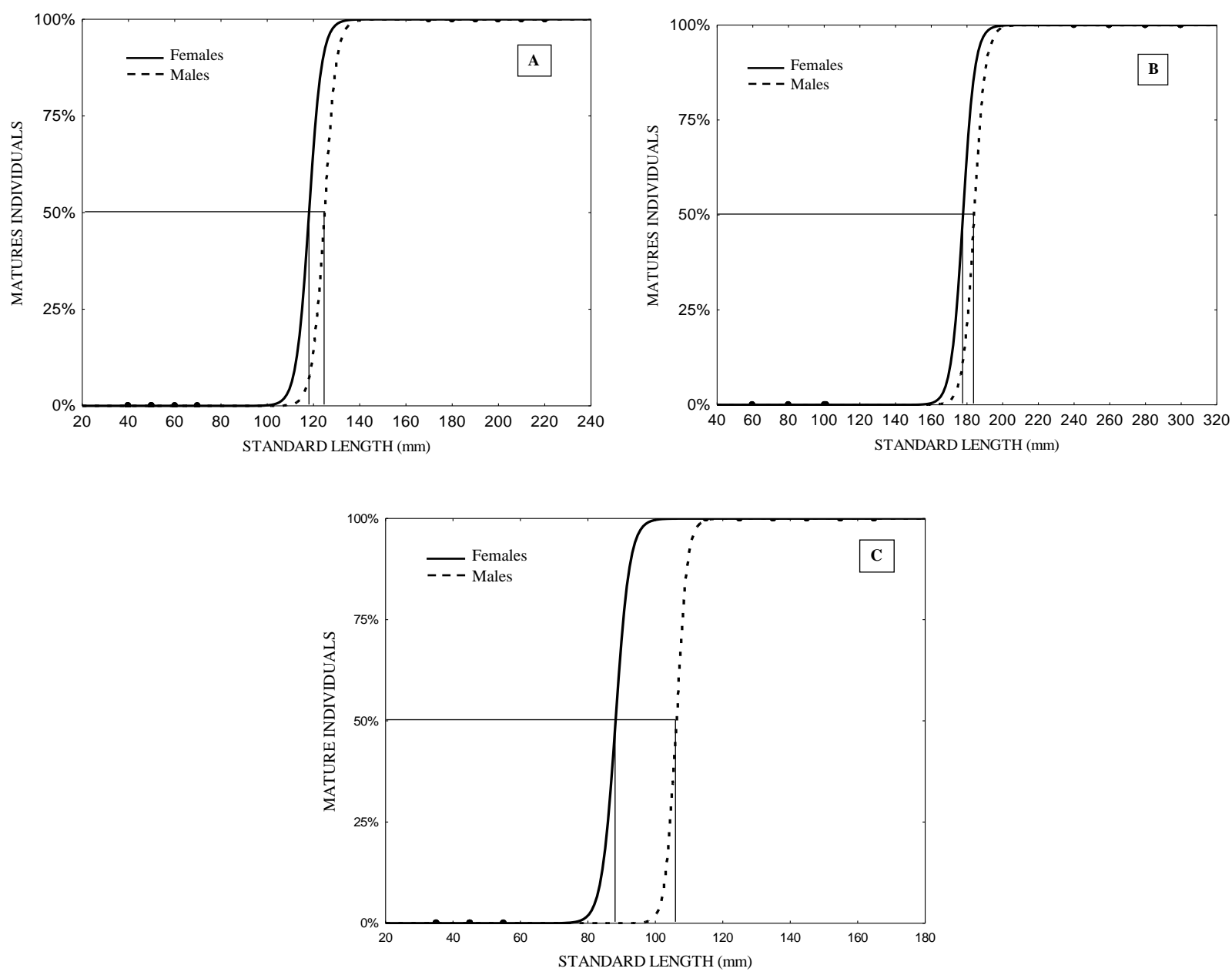

Figure 5. Logistic curves for estimation of the size at first sexual maturity (L50) of S. melanotheron (A), C. nogrodigitatus (B) and B. macrolepidotus (C) in Lake Ayamé 1 during September 2017 to August 2018.

Table 1. Absolute and relative fecundity of $S$. melanotheron, C. nigrodigitatus and B. macrolepidotus in Lake Ayamé 1 during September 2017 to August 2018. SD: Standard deviation

\begin{tabular}{llccc}
\hline & & S. melanotheron (32) & C. nigrodigitatus (42) & B. macrolepidotus (24) \\
\hline Standard lenght (mm) & Min - max & $150-220$ & $115-300$ & $90-200$ \\
Weight (g) & Min - max & $110.4-315$ & $94.5-340.8$ & $71.85-260.78$ \\
Absoltute fecundity & Min - max & $135-768$ & $2583-8081$ & $3386-43189$ \\
& Mean \pm SD & $386 \pm 146$ & $4307 \pm 1649$ & $22243 \pm 14331$ \\
& & & & \\
Relative fecundity & Min - max & $1-4$ & $15-36$ & $40-294$ \\
(eggs per gram ) & Mean \pm SD & $2 \pm 0.5$ & $23 \pm 5$ & $152 \pm 85$ \\
\hline
\end{tabular}

obtained in this study were smaller than those observed in other aquatic systems in Côte d'Ivoire $\left(\mathrm{SL}_{50}=195 \mathrm{~mm}\right.$ and $180 \mathrm{~mm}$ in C. nigrodigitatus and B. macrolepidotus, respectively) (Albaret 1982). For both species $S$. melanotheron and $C$. nigrodigitatus, males reached $S L_{50}$ at smaller length than female. These comparisons indicate a relative decline in the size of first maturity of species.

These variations may be attributed to the increase in fishing effort, environmental factors, population densities and food availability (Hossain et al., 2012). Indeed, Lake Ayamé 1 is under high pressure from non-native fishermen using non-selective gear (Tah et al., 2009). According to several authors, the size at first sexual 


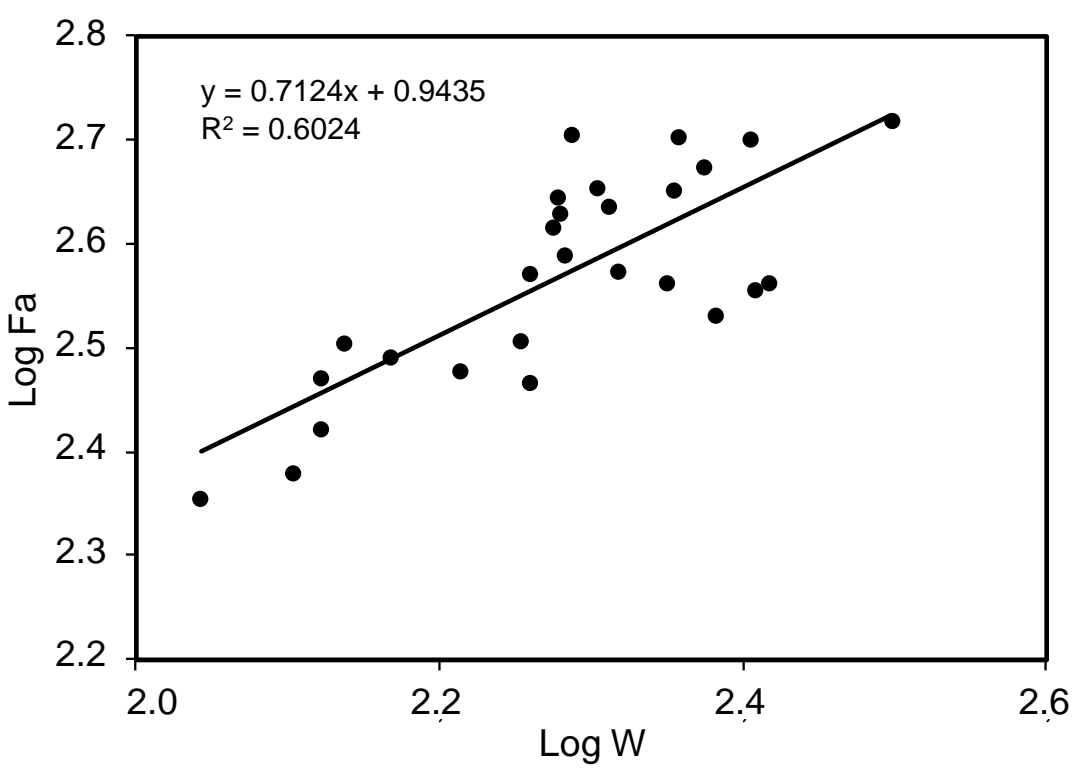

Figure 6. Regression curve showing relationship between Absolute Fecundity (Fa) and body weight of $S$. melanotheron from Lake Ayamé 1 between September 2017 and August 2018.
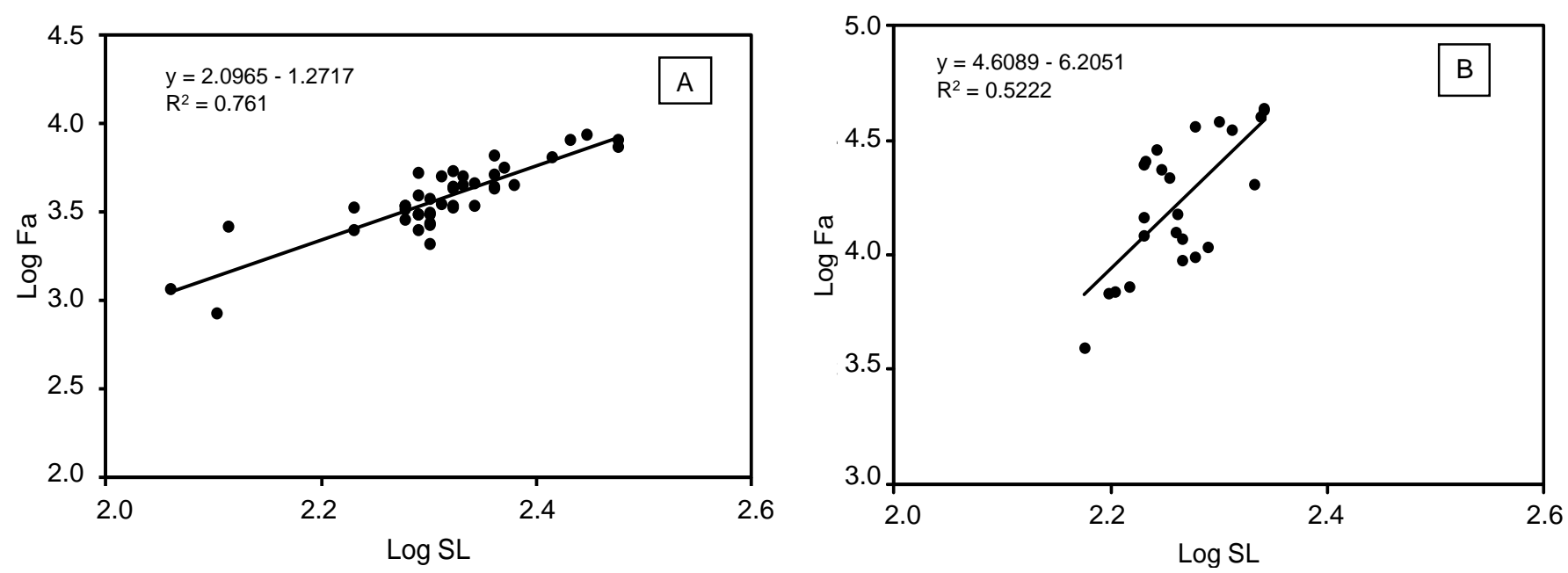

Figure 7. Regression curve showing relationship between Absolute Fecundity (Fa) and standard length (SL) of $C$. nigrodigitatus (A) and B. macrolepidotus (B) from lake Ayamé 1 between September 2017 and August 2018.

maturity is under strong evolutionary selection pressure in fish, and possible evolutionary changes toward a smaller maturation size could be observed due to high selective fishing pressure (Sharpe and Hendry, 2009; Vainikka and Hyvärinen, 2012). Increased fishing pressure generally tends to affect the size distribution of the adult stock recruited to a fishery by reducing the proportion of large individuals. Indeed, reducing the size of first sexual maturity is a strategy for species threatened to ensure the longevity of species (Duponchelle et al., 2000).

Fecundity of these three fish species in our study was comparable to other estimates for this species from lake Ayamé 1 and other aquatic systems. Koné and Teugels (1999) reported that fecundity of $S$. melanotheron varied from 132 to 430 eggs (122 to $175 \mathrm{~mm} \mathrm{SL}$ ) in Lake Ayamé 1 against fecundity ranging from 135 to 768 in this study (150 to $220 \mathrm{~mm} \mathrm{SL}$ ). Our results indicated that the relative fecundity of 2 eggs per $\mathrm{g}$, was higher than other study reported by Legendre and Ecoutin (1996) of 1.7 eggs per $\mathrm{g}$, in Ebrié lagoon. Similarly, relative fecundity of 23 eggs per $g$ recorded for $C$. nigrodigitatus in this study is higher than 17 eggs per $g$ recorded for by Albaret (1982). These differences indicate a trend towards 
increasing fecundity in both species. Indeed, females from populations co-occurring with predatory fishes usually present higher fecundity, with smaller offspring size and reach maturity at a smaller size than females from predator free populations (Reznick et al., 1996; Johnson and Belk, 2001). Overfishing and predation also contribute to the decline of fish populations, thus the increase of fecundity may also be the result of a strategy to their continued existence as species. For $B$. macrolepidotus, a decrease in fecundity was observed in the present study (152 eggs per g) in contrast to the findings by Albaret (1982) and Paugy (1982) that reported of 180 to 182 eggs per $\mathrm{g}$. This decline may be related to significant decrease in the size of the first maturity from $180 \mathrm{~mm}$ (Albaret, 1982) to $88 \mathrm{~mm}$ in females. Fecundity in teleosts could be affected by food availability, female condition, size and the environmental conditions (MuRua and Motos, 2006; Dominguez-Petit and Saborido-Rey 2010). Thus, for a given size, females live in better condition exhibit higher fecundity (Kjesbu et al., 1991), indicating that size and condition are the key parameters to properly assess fecundity at the population level.

The results of the present work suggest that the relation between the absolute fecundity and the standard length or weight can be formulated as a linear one and high determination coefficients were obtained in $C$. nigrodigitatus and B. macrolepidotus. Demska-Zakes and Dlugosz (1995) believed that fish with such relations show faster growth rate at the same tune with higher fecundity and that the parameters to a large extent depend on the environmental conditions. Positive relationships between fecundity and length have been reported for different fish species from different geographical areas (Hossain et al., 2012; Konan et al., 2014), and this lends support to the present results.

\section{CONCLUSION}

The results of this study showed a tendency to modify the reproductive traits, in particular by decreasing sizes at first sexual maturity and suggest a strategy of adaptation to overfishing by increasing the fecundity index in $S$. melanotheron and C. nigrodigitatus. In view of the reduction in sizes, the use of non-selective fishing gear should be discouraged and the reduction of fishing effort in rainy season (June and July) to manage resources rationally. However, further study is recommended to assess the exploited fish stocks in Lake Ayamé 1.

\section{ACKNOWLEDGEMENTS}

The authors wish to acknowledge The Fisheries and Aquaculture Management (DAP), the Support Program for the Sustainable Management of Fishery Resources (PAGDRH) that contributed financially to this work. We also thank Cissé Mamadou, Mobio Atoulé Edouard, Aka Tanoh Simon and fishermen who took part in data collection.

\section{REFERENCES}

Albaret JJ, 1982. Reproduction et fécondité des poissons d'eau douce de Côte-d'Ivoire. Rev hydrobiol Trop, 15: 347-371.

Costa EFS, Dias JF, Murua H, 2015. Reproductive strategy and fecundity of the keystone species Paralonchurus brasiliensis (Teleoestei, Sciaenidae): an image processing techniques application. Environ Biol Fish, 96: 2093-2108.

Demska-Zakes K, Dlugosz M, 1995. Fecundity of vendace from two lakes of Mazurian district. Rybna, 31: 37-50.

Dominguez-Petit R, Saborido-Rey F, 2010. New bioenergetic perspective of European hake (Merluccius merluccius L.) reproductive ecology. Fish Res, 104: 83-88.

Duponchelle F, Cecchi P, Corbin D, Nunez J, Legendre M, 2000. Variations in fecundity and egg size offemale Nile tilapia, Oreochromisniloticus, populations from man-madelakes of Côte d'Ivoire. Environ Biol Fish, 57: 155-170.

Durand JR, Loubens G, 1970. Observation sur la sexualité et la reproduction des Alestes baremoze du lac Chari et du lac Tchad. Cah ORSTOM Sér hydrobiol, 5: 61-81.

Hossain MY, Mosaddequr RM, Miranda R, Leunda PM, Oscoz J, Jewel MAS, Naif A, Ohtomi J, 2012. Size at first sexual maturity, fecundity, length-weight and length-length relationships of Puntius sophore (Cyprinidae) in Bangladeshi waters. J Appl Ichthyol, 28: 818-822.

Johnson JB, Belk MC, 2001. Predation environment predicts divergent lifehistory phenotypes among populations of the livebearing fish Brachyrhaphis rhabdophora. Oecologia, 126: 142-149.

Kjesbu OS, Klungsoyr J, Krivi H, Witthames PR, Greer WM, 1991. Fecundity, atresia, and egg size of captive Atlantic (Gadus morhua) in relation to proximate body composition. Can J Fish Aquat Sci, 48: 2333-2343.

Konan YA, Koné T, Bamba M, Koné I, 2014. Reproductive strategies of the catfish Clarias buettikoferi (Pisces, Clariidae) in the Tanoe-Ehy swamp forest (South-Eastern Côte d'Ivoire). World J Fish Mar Sci, 6: 16-23.

Koné $\mathrm{T}, 2000$. Régime alimentaire et reproduction d'un Tilapia lagunaire (Sarotherodon melanotheron Ruppel, 1852) dans la rivière Bia et le lac de barrage d'Ayamé. Thèse de Doctorat, Katholieke Universiteit Leuven, Belgique.

Koné T, Teugels GG, 1999. Données sur la reproduction d'un tilapia estuarien (Sarotherodon melanotheron) isolé dans un lac de barrage ouest-africain. Aquat Living Resour, 12: 289-293.

Laë $R, 1997$. Estimation des rendements de pêche des lacs africains au moyen de modèles empiriques. Aquat Living Resour, 10: 83-92.

Lalèyè $\mathrm{P}, 1995$. Ecologie comparée des deux espèces de Chrysichthys poissons siluriformes (Claroteidae) du complexe lagunaire $<<l a c$ Nokoué-lagune de Porto-Novo >> au Bénin. Thèse de Doctorat. Université de Liège, Belgique.

Lambert Y, Yaragina NA, Kraus G, Marteinsdottir G, Wright PJ, 2003. Using environmental and biological indices as proxies for egg and larval production of marine fish. J Northwest Atl Fish Sci, 33: 115159.

Legendre M, Ecoutin JM, 1996. Aspects de la stratégie de reproduction de Sarotherodon melanotberon,comparaison entre une population naturelle (lagune Ebrié, Côte d'Ivoire) et différentes populations d'élevage. In:Le Troisième Symposium International sur le Tilapia en Aquaculture, Pullin RSV, Lazard J, Legendre M, Amon Kothias JB, Pauly D. (Eds), ICLARM Conference Proceedings. pp: 360-374.

Lévêque C, Paugy D, Duponchelle F, 2006. La Reproduction. In: Les poissons des eaux continentales africaines: diversité, écologie, utilisation par l'homme, Lévêque C, Paugy D (Eds), IRD Éditions, Paris, pp: 147-176.

Lowe-McConnell RH, 1975. Fish communities in tropical freshwaters. Longman, London.

Murua H, Motos L, 2006. Reproductive strategy and spawning activity 
of the European hake Merluccius merllucius (L.) in the Bay of Biscay. J Fish Biol, 69: 1288-1303.

Ouattara M, Gourène G, Vanga AF, 2006. Propositions de fermeture saisonnière de la pêche en vue d'une exploitation durable du poisson au lac d'Ayamé (Côte d'ivoire). Tropicultura, 24: 7-13.

Paugy D, 1982. Synonymie d'Alestes rutilus Boulenger, 1916 avec $A$. macrolepidotus Valenciennes, 1849: biologie et variabilité morphologique. Rev Zool Afr, 96: 286-315.

Paugy D. 2003. Alestidae. In: The fresh and brackfish water fishes of West Africa, Paugy D., Lévêque C., Teugels G.G. (Eds), IRD Editions. National Museum of Natural History, RMCA, Volume 1, pp: 236-282.

Reznick D, Callahan H, Llauredo R, 1996. Maternal effects on offspring quality in Poeciliid fishes. Am Zool, 36: 147-156.

Risch LM, 2003. Claroteidae. In: The fresh and brackfish water fishes of West Africa, Paugy D., Lévêque C., Teugels G.G. (Eds), IRD Editions. National Museum of Natural History, RMCA, Volume 2, pp: 60-96.

Rochet MJ, Cornillon PA, Sabatier R, Pontier D, 2000. Comparative analysis of phylogenetic and fishing effects in life history pattern of teleost fishes. Oikos, 91: 255-270.

Saborido-Rey F, Kjesbu OS, 2005. Growth and maturation dynamics. Digital CSIC book, $26 \mathrm{pp}$.

Saila SB, Recksiek CW, Prager MH, 1988. Basic fishery science programs: A compendium of microcomputer programs and manual of operation. Elsevier Science Publishers Co., New York,230 pp.

Sharpe D, Hendry A, 2009. Life history change in commercially exploited fish stocks: an analysis of trends across studies. Evol Appl, 2: $260-275$.

Stearns SC, 1992. The Evolution of Life Histories. Oxford University Press, New York, 249 pp.

Tah L, Da Costa KS, Kouassi JN, Moreau J, 2009. Effort de pêche et production piscicole au lac d'Ayamé I (Bassin de la Bia; Côte d'Ivoire) après le départ des pêcheurs «Bozos». Agron Afr, 21: 103-115.

Teugels GG, Thys Van Den Audenaerde DFE, 2003. Cichlidae. In: The fresh and brackfish water fishes of West Africa, Paugy D., Lévêque C., Teugels G.G. (Eds), IRD Editions. National Museum of Natural History, RMCA, Volume 2, pp: 521-600.

Trippel EA, Kjesbu OS, Solemdal P, 1997. Effects of adult age and size structure on reproductive output in marine fishes. In: Early Life History and Recruitment in Fish Populations, Chambers RC, Trippel EA (Eds), Chapman and Hall, London, UK, pp: 31-62.

Vainikka A, Hyvärinen $P, 2012$. Ecologically and evolutionarily sustainable fishing of the pikeperch Sander lucioperca: Lake Oulujärvi as an example. Fish Res, 113: 8-20.

Vanga AF, 2004. Conséquences socio-économiques de l'expulsion des pêcheurs étrangers en Côte d'ivoire : lacs d'Ayamé et de Buyo. Rev Eur migr inter, 20: 1-9.
Welcomme RL, de Merona B, 1988. Fish communities of rivers. In: Biology and Ecology of African Freshwater fishes, Lévêque C, Bruton MN, Ssentongo GW (Eds), Editions de l'ORSTOM. Collection Travaux et Documents (216), Paris, pp: 251-276.

Yeldan H, Avsar D, 2000. A preliminary study on the reproduction of the rabbitfish (Siganus rivulatus Forsskal, 1775) in northeastern Mediterranean. Turk J Zool, 24: 173-182.
Citation: Kessié BA, Konan YA, Kamelan TM, Kouamélan EP, 2019. Some reproductive traits of three fish species from Lake Ayamé 1 of the South-Eastern Côte d'Ivoire. Net J Agric Sci, 7(1): 34-42. 